PENGARUH DAYA TARIK WISATA DAN HARGA TERHADAP KEPUTUSAN BERKUNJUNG DI WISATA PANTAI BIRU KERSIK MARANGKAYU

Laili Nur Rahmawati dan Fareis Althalets

Universitas Mulawarman, Indonesia

E-mail: lailinr98@gmail.com dan althaletsfareis@gmail.com

\section{Diterima:}

26 Desember

2021

Direvisi:

09 Januari 2022

Disetujui:

15 Januari 202

\section{Abstrak}

Latar Belakang : Indonesia adalah suatu negara yang menyandang sebagai negara kepulauan dengan sisi geografisnya sehingga secara alamiah juga membentuk berbagai macam keanekaragaman alam, manusia dan budaya uniknya dari masing-masing daerah. Tujuan : Penelitian ini bertujuan untuk mengetahui: (1) pengaruh daya tarik wisata terhadap keputusan berkunjung, (2) pengaruh harga terhadap keputusan berkunjung dan (3) pengaruh daya tarik wisata dan harga terhadap keputusan berkunjung. Dalam penelitian ini objek yang diteliti adalah Pantai Biru Kersik yang terletak di Kecamatan Marangkayu, Kabupaten Kutai Kartanegara. Metode : Penelitian ini menggunakan metode pendekatan kuantitatif. Populasi dalam penelitian ini adalah pengunjung objek wisata Pantai Biru Kersik. Teknik pengambilan sampel menggunakan accidental sampling dengan jumlah sampel sebanyak 97 orang. Teknik pengumpulan data menggunakan teknik observasi, kuesioner dan dokumetasi yang telah diuji validitasnya dan reliabilitasnya. Teknik analisis data yang digunakan adalah uji validitas, uji reliabilitas, uji asumsi klasik (uji normalitas, uji multikolinieritas dan uji heteroskedastisitas), analisis regresi linier berganda, uji hipotesis (uji t dan uji F) dan uji koefisien determinasi. Hasil : Hasil penelitian menunjukkan bahwa daya tarik wisata dan harga secara parsial berpengaruh terhadap keputusan berkunjung di wisata Pantai Biru Kersik Marangkayu. Daya tarik wisata dan harga secara simultan berpengaruh terhadap keputusan berkunjung di wisata Pantai Biru Kersik Marangkayu. Kesimpulan : Variabel daya tarik wisata dan harga secara simultan berpengaruh terhadap keputusan berkunjung di wisata pantai biru kersik marangkayu, Variabel daya tarik wisata dan harga secara parsial berpengaruh terhadap keputusan berkunjung di wisata pantai biru kersik marangkayu.

Kata kunci: Daya Tarik Wisata, Harga, Keputusan

$$
\text { Berkunjung }
$$

\section{Abstract}

Background : Indonesia is a country that bears the status of an archipelagic country with its geographical side so that naturally it also forms various kinds of natural, human and cultural diversity unique to each region. Purpose : This study aims to determine: (1) the effect of tourist attraction on the 


\title{
Pengaruh Daya Tarik Wisata Dan Harga Terhadap Keputusan Berkunjung di Wisata Pantai Biru Kersik Marangkayu
}

\begin{abstract}
decision to visit, (2) the effect of price on the decision to visit and (3) the influence of tourist attraction and price on the decision to visit. In this study, the object under study is Blue Kersik Beach which is located in Marangkayu District, Kutai Kartanegara Regency. Method: This research uses a quantitative approach method. The population in this study were visitors to the Blue Kersik Beach tourist attraction. The sampling technique used accidental sampling with a total sample of 97 people. Data collection techniques using observation techniques, questionnaires and documentation that have been tested for validity and reliability. The data analysis techniques used are validity test, reliability test, classical assumption test (normality test, multicollinearity test and heteroscedasticity test), multiple linear regression analysis, hypothesis testing ( $t$ test and $F$ test) and coefficient of determination test. Results : The results showed that tourist attraction and price partially influenced the decision to visit the Blue Kersik Beach Marangkayu tourism. Tourist attraction and price simultaneously affect the decision to visit the Blue Kersik Beach, Marangkayu. Conclusion : Variables of tourist attraction and price simultaneously influence the decision to visit the Blue Kersik beach, Marangkayu.

Keywords: Tourist attraction, Price, Visit Decision
\end{abstract}

\section{Pendahuluan}

Indonesia adalah negara yang menyandang sebagai negara kepulauan dengan sisi geografisnya sehingga secara alamiah juga membentuk berbagai macam keanekaragaman alam, manusia dan budaya uniknya dari masing-masing daerah (Armawi, 2020). Secara garis besar kapasitas pariwisata di Indonesia meliputi hampir semua jenis wisata yang bisa ditawarkan kepada wisatawan, seperti wisata alam, wisata budaya dan bermacammacam wisata lainnya sebagai produk ciptaan manusia dengan ciri khasnya sendiri yang ada pada daerahnya masing-masing (Luturlean \& SE, 2019). Sehingga tak heran jika Indonesia sering atau bahkan digemari oleh wisatawan mancanegara untuk dikunjungi. Pariwisata secara tidak langsung berhubungan erat dengan aktivitas perekonomian, pariwisata berdampak juga bagi para pengusaha rumah makan, akomodasi dan fasilitas lainnya. Ketentuan yang wajib dipenuhi agar sukses dalam meningkatkan keputusan berkunjung pariwisata adalah dengan berusaha untuk menciptakan ide, kreasi dan inovasi objek wisata bagi pengelola (Isdarmanto, 2020).

Undang-undang Dasar No. 10 Tahun 2009 Daya tarik wisata adalah segala sesuatu yang memiliki keunikan, keindahan, dan nilai yang berupa keanekaragaman kekayaan alam, budaya, dan hasil buatan manusia yang menjadi sasaran atau tujuan kunjungan wisatawan (Brahmanto \& Hamzah, 2017). Daya Tarik wisata, potensi yang menjadi pendorong utama wisatawan untuk mengunjungi suatu kawasan objek wisata adalah Daya Tarik Wisata (Attraction), aksesbilitas (Accessibility), amenitas (Amenity), dan fasilitas tambahan (Ancillary) sebagaimana disebut sebagai 4A (Pundissing, 2021).

Kualitas jasa sangat dipengaruhi oleh harga karena semakin mahal harga maka semakin sedikit pula jumlah permintaan produk jasa yang bersangkutan begitu juga sebaliknya. Harga sebagai alat untuk menukar, harga adalah jumlah yang ditagihkan atas 
suatu produk atau jasa (Paulus A \& Ellen G, 2016). Faktor utama yang menjadi pengaruh pilihan para pembeli ialah harga dan harga juga menjadi komponen penting dari biaya fasilitas, biaya angkutan dan biaya atraksi wisata (Arifin, 2016). Terdapat 4 indikator yang digunakan untuk penentuan harga yaitu keterjangkauan harga, kesesuaian harga dengan kualitas produk, daya saing harga dan kesesuaian harga dengan manfaat (Lubis, 2018).

Keputusan berkunjung akan tercapai jika pengelola memperhatikan baik faktor daya tarik wisata dan harga (Saputra \& Suryoko, 2018). Faktor yang dapat mempengaruhi pengambilan keputusan seorang wisatawan adalah karakteristik wisatawan, kesadaran akan manfaat perjalanan, gambaran perjalanan dan keunggulan daerah tujuan wisata (Ibrahim \& Eryani, 2014).

Peneliti mengambil obyek wisata pantai biru kersik di Kecamatan Marangkayu Kabupaten Kutai kartanegara. Lokasi tempat wisata tersebut terbilang jauh dari pusat kota Samarinda dengan jarak $\pm 95,8 \mathrm{Km}$ dan masih terbilang sulit ditemui karena kurangnya petunjuk arah. Fasilitas yang tersedia cukup lengkap diantaranya terdapat wc/kamar mandi, musholla, gazebo, rumah makan dan bagi wisatawan yang ingin menginap juga terdapat banyak penyewaan homestay didekat pantai biru kersik tersebut. Untuk harga yang ditawarkan pantai biru kersik sendiri terbilang cukup murah untuk tiket masuk di obyek wisata pantai biru kersik sendiri hanya menghitung perkendaraan saja sebesar Rp. 5.000 untuk motor dan Rp.20.000 untuk mobil. Namun untuk harga penyewaan gazebo sendiri masih terbilang cukup mahal karena untuk menyewa satu tempat yang ukurannya tidak terlalu besar saja harus membayar sebesar Rp. 50.000 akan tetapi banyak pengunjung yang menyewa dan menggunakan gazebo tersebut.

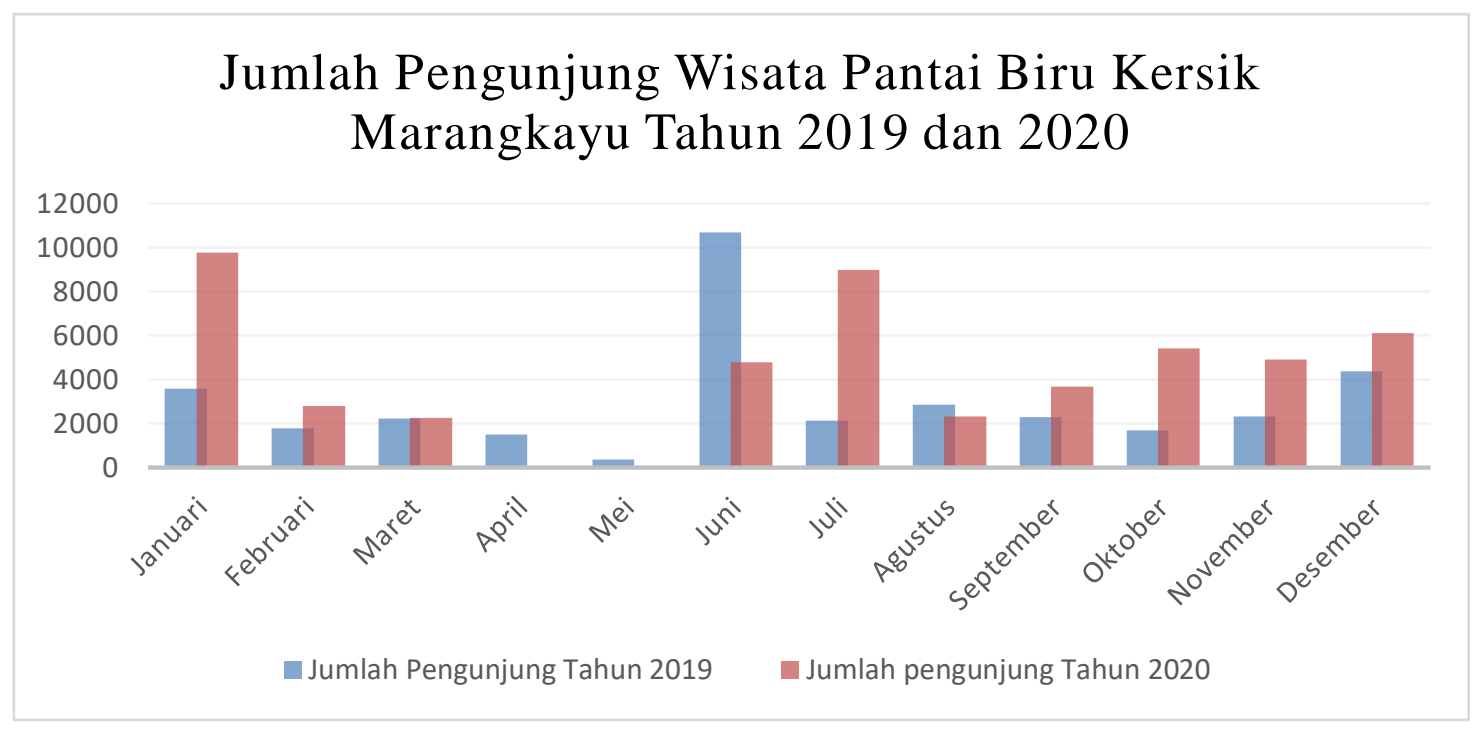

Gambar 1. Jumlah Pengunjung Wisata Pantai Biru Kersik Marangkayu Tahun 2019 dan 2020

Sumber data: Pengelola Wisata Pantai Biru Kersik (2020)

Berdasarkan gambar diatas, terlihat bahwa jumlah pengunjung dari tahun 2019 ke tahun 2020 mengalami kenaikan yang signifikakn walaupun pada bulan April dan Mei tahun 2020 tidak ada kunjungan sama sekali dikarenakan adanya pandemi covid-19 yang mengharuskan tempat wisata untuk tutup sementara waktu dan jumlah kunjungan perbulannya terkadang mengalami kenaikan yang signifikan dan terkadang mengalami 
penurunan yang signifikan. Maka dari itu pengelola harus lebih memperhatikan dan meningkatkan daya tarik wisata dan harga di pantai biru kersik tersebut.

Berdasarkan latar belakang di atas, maka perumusan masalah dari penelitian ini adalah sebagai berikut, apakah daya tarik wisata dan harga secara parsial berpengaruh terhadap keputusan berkunjung di wisata pantai biru kersik marangkayu. Tujuan penelitian ini adalah untuk mengukur dan menganalisis tingkat signifikan secara parsial pengaruh daya tarik wisata dan harga terhadap keputusan berkunjung di wisata pantai biru kersik marangkayu.

\section{Metode Penelitian}

Sesuai dengan judul penelitian yang diambil yakni tentang "Pengaruh Daya Tarik Wisata, Harga Dan Promosi Terhadap Keputusan Berkunjung Di Wisata Pantai Biru Kersik Marangkayu", untuk mendapatkan gambaran yang lebih mendalam dan berusaha untuk melakukan pemecahan masalah yang ada berdasarkan data dan informasi maka penelitian ini akan dianalisis menggunakan metode pendekatan kuantitatif. Populasi yang digunakan peneliti adalah pengunjung pantai biru kersik marangkayu. Sampel yang digunakan sebanyak 97 responden dengan teknik pengambilan sampel yang digunakan adalah pendekatan non probability sampling yaitu teknik sampling yang tidak memberikan kesempatan sama bagi setiap unsur atau anggota populasi untuk dijadikan sampel.

\section{Hasil dan Pembahasan}

Tabel 1. Hasil Uji Validitas

\begin{tabular}{|c|c|c|c|c|}
\hline Variabel & Kode Item & R hitung & R tabel & Keterangan \\
\hline \multirow{8}{*}{$\begin{array}{l}\text { Daya Tarik } \\
\text { Wisata (X1) }\end{array}$} & $\mathrm{X} 1.1$ & 0.560 & 0.197 & VALID \\
\hline & $\mathrm{X} 1.2$ & 0.554 & 0.197 & VALID \\
\hline & $\mathrm{X} 1.3$ & 0.615 & 0.197 & VALID \\
\hline & $\mathrm{X} 1.4$ & 0.583 & 0.197 & VALID \\
\hline & $\mathrm{X} 1.5$ & 0.563 & 0.197 & VALID \\
\hline & $\mathrm{X} 1.6$ & 0.699 & 0.197 & VALID \\
\hline & $\mathrm{X} 1.7$ & 0.540 & 0.197 & VALID \\
\hline & $\mathrm{X} 1.8$ & 0.632 & 0.197 & VALID \\
\hline \multirow{8}{*}{ Harga (X2) } & $\mathrm{X} 2.1$ & 0.638 & 0.197 & VALID \\
\hline & $\mathrm{X} 2.2$ & 0.648 & 0.197 & VALID \\
\hline & $\mathrm{X} 2.3$ & 0.754 & 0.197 & VALID \\
\hline & $\mathrm{X} 2.4$ & 0.702 & 0.197 & VALID \\
\hline & $\mathrm{X} 2.5$ & 0.724 & 0.197 & VALID \\
\hline & $\mathrm{X} 2.6$ & 0.823 & 0.197 & VALID \\
\hline & $\mathrm{X} 2.7$ & 0.783 & 0.197 & VALID \\
\hline & $\mathrm{X} 2.8$ & 0.680 & 0.197 & VALID \\
\hline \multirow{3}{*}{$\begin{array}{c}\text { Keputusan } \\
\text { Berkunjung (Y) }\end{array}$} & Y.1 & 0.678 & 0.197 & VALID \\
\hline & Y.2 & 0.629 & 0.197 & VALID \\
\hline & Y.3 & 0.616 & 0.197 & VALID \\
\hline
\end{tabular}




\begin{tabular}{llll} 
Y.4 & 0.612 & 0.197 & VALID \\
\hline Y.5 & 0.668 & 0.197 & VALID \\
\hline Y.6 & 0.689 & 0.197 & VALID \\
\hline Y.7 & 0.659 & 0.197 & VALID \\
\hline Y.8 & 0.693 & 0.197 & VALID
\end{tabular}

Sumber: Hasil Pengolahan Data SPSS (versi 25), 2021

Nilai Cerrected item-Total Correlation ( $\mathrm{r}$ hitung) yang kurang dari $\mathrm{r}$ tabel menunjukan bahwa pernyataan tidak mampu mengukur variabel yang ingin diukur, namun apabila $\mathrm{r}$ hitung $>\mathrm{r}$ tabel maka pernyataan tersebut valid dan mampu mengukur variabel penelitian (Ghozali, 2013). Dari hasil perhitungan di atas dapat disimpulkan bahwa item pernyataan Daya Tarik Wisata (X1), Harga (X2) dan Keputusan Berkunjung (Y) dinyatakan valid.

Tabel 2. Hasil Uji Reliabilitas

\begin{tabular}{ccccc}
\hline No. & Variabel & $\begin{array}{c}\text { Cornbach's } \\
\text { Alpha }\end{array}$ & N of Item & Keterangan \\
\hline 1 & $\begin{array}{c}\text { Daya Tarik Wisata } \\
(\mathrm{X} 1)\end{array}$ & 0.729 & 8 & Reliabel \\
\hline 2 & Harga (X2) & 0.836 & 8 & Reliabel \\
\hline 3 & $\begin{array}{c}\text { Keputusan } \\
\text { Berkunjung(Y) }\end{array}$ & 0.803 & 8 & Reliabel \\
\hline
\end{tabular}

Sumber: Hasil Pengolahan Data SPSS (versi 25), 2021

Berdasarkan hasil uji reliabilitas di atas menunjukan bahwa ketiga variabel mempunyai nilai Cronbach Alpha > 0,60. Dapat disimpulkan bahwa variabel Daya Tarik Wisata, Harga dan Keputusan Berkunjung dinyatakan dapat dipercaya sebagai alat ukur.

Tabel 3. Hasil Uji Normalitas

One-Sample Kolmogorov-Smirnov Test

Unstandardized

Residual

\begin{tabular}{llr}
\hline N & & \multicolumn{2}{c}{ Residual } \\
\hline Normal Parameters & & 97 \\
& Mea & .0000000 \\
\cline { 2 - 3 } Most Extreme Differences & Std. Deviation & 2.62657886 \\
\cline { 2 - 3 } & Absolute & .084 \\
\cline { 2 - 3 } & Positive & .075 \\
\cline { 2 - 3 } & Negative & -.084 \\
\hline Test Statistic & & .084 \\
\hline Asymp. Sig. (2-tailed) & & $.088^{c}$ \\
\hline
\end{tabular}

a. Test distribution is Normal.

b. Calculated from data.

c. Lilliefors Significance Correction.

Sumber: Hasil Pengolahan Data SPSS (versi 25), 2021 
Berdasarkan tabel 3 nilai yang diperoleh dari uji Kolmogrov-smirnov sebesar 0,088 , nilai tersebut lebih besar dari 0,05 sehingga dapat dikatakan bahwa nilai berdistribusi secara normal dan memenuhi asumsi uji normalitas.

Tabel 4. Hasil Uji Multikolinieritas

\begin{tabular}{|c|c|c|c|c|c|c|c|c|}
\hline \multicolumn{9}{|c|}{ Coefficients $^{a}$} \\
\hline \multirow[b]{2}{*}{ Model } & & \multicolumn{2}{|c|}{$\begin{array}{l}\text { Unstandardized } \\
\text { Coefficients }\end{array}$} & \multirow{2}{*}{$\begin{array}{c}\text { Standardize } \\
\text { d } \\
\text { Coefficients } \\
\text { Beta } \\
\end{array}$} & \multirow[b]{2}{*}{$\mathrm{t}$} & \multirow[b]{2}{*}{ Sig. } & \multicolumn{2}{|c|}{$\begin{array}{c}\text { Collinearity } \\
\text { Statistics }\end{array}$} \\
\hline & & $\mathrm{B}$ & $\begin{array}{c}\text { Std. } \\
\text { Error }\end{array}$ & & & & $\begin{array}{c}\text { Toleranc } \\
\mathrm{e} \\
\end{array}$ & VIF \\
\hline 1 & $\begin{array}{l}\text { (Constant } \\
\text { ) }\end{array}$ & 3.075 & 2.375 & & 1.295 & .199 & & \\
\hline & $\begin{array}{l}\text { Daya } \\
\text { Tarik } \\
\text { Wisata }\end{array}$ & .399 & .087 & .357 & 4.583 & .000 & .677 & 1.478 \\
\hline & Harga & .524 & .078 & .525 & 6.743 & .000 & .677 & 1.478 \\
\hline
\end{tabular}

a. Dependent Variable: Keputusan Berkunjung

Sumber: Hasil Pengolahan Data SPSS (versi 25), 2021

Berdasarkan tabel 4 menunjukan bahwa hasil uji multikolinieritas bahwa nilai VIF untuk variabel daya tarik wisata $(\mathrm{X} 1)$ dan harga $(\mathrm{X} 2)$ adalah $1,478<10$. Nilai tolerance daya tarik wisata (X1) dan harga (X2) adalah $0,677>0,1$. Dapat disimpulkan bahwa semua variabel pada penelitian ini tidak terjadi multikolinieritas.

Tabel 5. Hasil Uji Heteroskedastisitas

\begin{tabular}{|c|c|c|c|c|c|c|}
\hline \multicolumn{7}{|c|}{ Coefficients $^{\mathrm{a}}$} \\
\hline \multirow[b]{2}{*}{ Model } & & \multicolumn{2}{|c|}{$\begin{array}{l}\text { Unstandardized } \\
\text { Coefficients }\end{array}$} & \multirow{2}{*}{$\begin{array}{c}\text { Standardized } \\
\text { Coefficients } \\
\text { Beta } \\
\end{array}$} & \multirow[b]{2}{*}{$\mathrm{t}$} & \multirow[b]{2}{*}{ Sig. } \\
\hline & & $\mathrm{B}$ & Std. Error & & & \\
\hline \multirow[t]{3}{*}{1} & (Constant) & 1.751 & 1.582 & & 1.106 & .271 \\
\hline & $\begin{array}{l}\text { Daya Tarik } \\
\text { Wisata }\end{array}$ & .007 & .058 & .015 & .124 & .902 \\
\hline & Harga & -.001 & .052 & -.002 & -.012 & .990 \\
\hline
\end{tabular}

Sumber: Hasil Pengolahan Data SPSS (versi 25), 2021

Berdasarkan grafik 5 dapat dilihat bahwa nilai signifikan untuk variabel daya tarik wisata sebesar 0,902 dan harga sebesar 0,990 yang mana semua nilai signifikan > 0,05. Hal ini dapat disimpulkan bahwa tidak terjadi gejala heteroskedastisitas pada model regresi, sehingga model regresi layak dipakai. 
Tabel 6. Hasil Analisis Regresi Linier Berganda

\begin{tabular}{|c|c|c|c|c|c|c|}
\hline \multicolumn{7}{|c|}{ Coefficients $^{a}$} \\
\hline & & \multicolumn{2}{|c|}{$\begin{array}{l}\text { Unstandardized } \\
\text { Coefficients }\end{array}$} & \multirow{2}{*}{$\begin{array}{l}\text { Standardize } \\
\text { d } \\
\text { Coefficients } \\
\\
\text { Beta } \\
\end{array}$} & \multirow[b]{2}{*}{$\mathrm{t}$} & \multirow[b]{2}{*}{ Sig. } \\
\hline Model & & $\mathrm{B}$ & $\begin{array}{l}\text { Std. } \\
\text { Error }\end{array}$ & & & \\
\hline \multirow[t]{5}{*}{1} & (Constant) & 3.075 & 2.375 & & 1.295 & .199 \\
\hline & Daya & .399 & .087 & .357 & 4.583 & .000 \\
\hline & Tarik & & & & & \\
\hline & Wisata & & & & & \\
\hline & Harga & .524 & .078 & .525 & 6.743 & .000 \\
\hline
\end{tabular}

a. Dependent Variable: Keputusan Berkunjung

Sumber: Hasil Pengolahan Data SPSS (versi 25), 2021

Berdasarkan tabel 6 dapat dilihat bahwa nilai konstanta (nilai $\alpha$ ) sebesar 3,075, untuk daya tarik wisata X1 (nilai $\beta$ ) sebesar 0,399 , dan untuk harga X2 (nilai $\beta$ ) sebesar 0,524 . Berikut adalah persamaan regresi linier berganda:

$$
Y=3,075+0,399 X_{1}+0,524 X_{2}
$$

Berikut ini adalah penjelasan persamaan regresi linier berganda:

1. Nilai konstanta $(\alpha)$ sebesar 3,075. Menunjukan bahwa nilai konstan, dimana jika variabel daya tarik wisata (X1) dan harga (X2) adalah nol (0), maka keputusan berkunjung (Y) adalah 3,075.

2. Nilai koefisien regresi variabel daya tarik wisata (X1) sebesar 0,399. Menunjukan bahwa jika terjadi peningkatan daya tarik wisata (X1) sebesar $1 \%$ maka keputusan berkunjung (Y) akan meningkat sebesar 0,399.

3. Nilai koefisien regresi variabel harga (X2) sebesar 0,524. Menunjukan bahwa jika terjadi peningkatan harga (X2) sebesar $1 \%$ maka keputusan berkunjung (Y) akan meningkat sebesar 0,524 . 
Tabel 7. Hasil Uji T

\begin{tabular}{|c|c|c|c|c|c|c|}
\hline \multicolumn{7}{|c|}{ Coefficients $^{\mathrm{a}}$} \\
\hline & & \multicolumn{2}{|c|}{$\begin{array}{c}\text { Unstandardized } \\
\text { Coefficients }\end{array}$} & \multirow{2}{*}{$\begin{array}{l}\text { Standardize } \\
\text { d } \\
\text { Coefficients } \\
\text { Beta } \\
\end{array}$} & \multirow[b]{2}{*}{$\mathrm{t}$} & \multirow[b]{2}{*}{ Sig. } \\
\hline Model & & $\mathrm{B}$ & $\begin{array}{l}\text { Std. } \\
\text { Error }\end{array}$ & & & \\
\hline \multirow[t]{5}{*}{1} & (Constant) & 3.075 & 2.375 & & 1.295 & .199 \\
\hline & Daya & .399 & .087 & .357 & 4.583 & .000 \\
\hline & Tarik & & & & & \\
\hline & Wisata & & & & & \\
\hline & Harga & .524 & .078 & .525 & 6.743 & .000 \\
\hline
\end{tabular}

a. Dependent Variable: Keputusan Berkunjung

Sumber: Hasil Pengolahan Data SPSS (versi 25), 2021

Berdasarkan tabel 7 dapat diketahui mengenai hasil uji t adalah sebagai berikut:

1. Daya Tarik Wisata (X1)

Dapat dilihat pada tabel di atas bahwa daya tarik wisata (X1) memiliki $t$ hitung $>\mathrm{t}$ tabel $(4,583>1,661)$ dan nilai sig < $0,05(0,000<0,05)$ maka H0 ditolak dan H1 diterima. Dapat disimpulkan bahwa daya tarik wisata berpengaruh positif terhadap keputusan berkunjung. 2. Harga (X2)

Dapat dilihat pada tabel di atas bahwa harga (X2) memiliki $t_{\text {hitung }}>\mathrm{t}_{\text {tabel }}(6,743>1,661)$ dan nilai sig $<0,05(0,000<0,05)$ maka H0 ditolak dan H1 diterima. Dapat disimpulkan bahwa harga berpengaruh positif terhadap keputusan berkunjung.

Tabel 8. Hasil Uji F

\begin{tabular}{|c|c|c|c|c|c|c|}
\hline \multicolumn{7}{|c|}{ ANOVA $^{\mathrm{a}}$} \\
\hline Model & & Sum of Squares & df & Mean Square & $\mathrm{F}$ & Sig. \\
\hline \multirow[t]{3}{*}{1} & Regression & 1057.931 & 2 & 528.965 & 75.076 & $.000^{\mathrm{b}}$ \\
\hline & Residual & 662.296 & 94 & 7.046 & & \\
\hline & Total & 1720.227 & 96 & & & \\
\hline
\end{tabular}

a. Dependent Variable: Keputusan Berkunjung

b. Predictors: (Constant), Harga, Daya Tarik Wisata

Sumber: Hasil Pengolahan Data SPSS (versi 25), 2021

Berdasarakan tabel 8 dapat dilihat bahwa dari setiap variabel berpengaruh secara simultan yaitu dengan nilai Fhitung $(75,076)>$ Ftabel $(3,09)$ atau sig sebesar $(0,000<$ 0,05). Dapat disimpulkan bahwa variabel bebas yaitu daya tarik wisata (X1) dan harga (X2) secara bersama-sama (simultan) berpengaruh positif dan signifikan terhadap variabel terikat yaitu keputusan berkunjung $(\mathrm{Y})$. 
Tabel 9. Hasil Uji Koefisien Determinasi $\left(\mathrm{R}^{2}\right)$

\begin{tabular}{lr|r|r|r}
\multicolumn{5}{c}{ Model Summary } \\
Model & $\mathrm{R}$ & R Square & Adjusted R Square & Std. Error of the Estimate \\
\hline 1 & $.784^{\mathrm{a}}$ & .615 & .607 & 2.654 \\
\hline
\end{tabular}

a. Predictors: (Constant), Harga, Daya Tarik Wisata

Sumber: Hasil Pengolahan Data SPSS (versi 25), 2021

Berdasarkan tabel 9 dapat dilihat hasil uji koefisien determinasi dalam penelitian ini diperoleh dari besarnya nilai adjusted $\mathrm{r}$ square adalah 0,607 yang artinya bahwa pengaruh variabel independen (X) terhadap variabel dependen (Y) sebesar 60,7\%. Berdasarkan hasil penelitian yang telah di ujikan tentang "Pengaruh Daya Tarik Wisata Dan Harga Terhadap Keputusan Berkunjung Di Wisata Pantai Biru Kersik Marangkayu" menjelaskan bahwa instrumen-instrumen data yang di jawab oleh responden adalah valid dan reliabel. Selanjutnya hasil tersebut diperoleh bahwa variabel daya tarik wisata dan harga secara parsial dan simultan berpengaruh positif terhadap keputusan berkunjung.

Daya Tarik Wisata merupakan segala sesuatu yang unik dan menarik bagi wisatawan untuk dikunjungi karena tempat tersebut memiliki makna tertentu seperti, keindahan linkungan alam, peninggalan tempat bersejarah dan peristiwa-peristiwa tertentu (Annisa, 2020). Dalam penelitian ini variabel daya tarik wisata memiliki empat indikator yaitu Attractions (atraksi), Accessibility (aksesibilitas), Amenity (amenitas) dan Ancillary (fasilitas tambahan) (Harianto, Winarno, Santoso, Tsani, \& Masruri, 2019).

Berdasarkan hasil penelitian menunjukkan bahwa variabel daya tarik wisata (X1) yang memiliki $\mathrm{t}$ hitung $>\mathrm{t}$ tabel $(4,583>1,661)$ dan nilai sig $<0,05(0,000<0,05)$. Penelitian ini berhasil membuktikan bahwa daya tarik wisata secara parsial berpengaruh positif dan signifikan terhadap keputusan berkunjung di wisata Pantai Biru Kersik dan sesuai dengan rumusan masalah dan hipotesis pertama dalam penelitian ini. Dapat diketahui bahwa dari hasil penelitian, responden setuju dengan Pantai Biru Kersik yang memiliki daya tarik wisata yang memiliki pemandangan yang indah dan keunikan alamnya, sehingga pengunjung dapat menikmati atraksi wisata yang menyenangkan. Artinya semakin baik daya tarik wisata yang terdapat di Pantai Biru Kersik sehingga pengunjung merasa nyaman terhadap atraksi, aksesibilitas, amenitas dan fasilitas pendukung lainnya yang tersedia, maka semakin meningkat pula jumlah keputusan berkunjung wisatawan ke pantai biru kersik tersebut.

Penelitian ini sejalan dengan penelitian terdahulu, karena nilai hasil penelitian ini menunjukkan bahwa daya tarik wisata berpengaruh positif dan signifikan terhadap keputusan berkunjung di wisata Pantai Biru Kersik dan memperkuat hasil penelitian milik Trisna Widjianto (2019) dengan judul "Pengaruh Daya Tarik Wisata, Citra Wisata, Promosi Dan kualitas Pelayanan Terhadap Minat Berkunjung Kembali Wisatawan Di Objek Wisata Ketep Pass" yang hasil penelitiannya menunjukkan bahwa Daya tarik wisata, citra wisata, promosi dan kualitas pelayanan berpengaruh positif terhadap minat kunjungan kembali wisatawan di objek wisata ketep pass Temuan ini juga sesuai dengan teori menurut Sunaryo (2013) potensi yang menjadi pendorong utama wisatawan untuk mengunjungi suatu kawasan objek wisata adalah Daya Tarik Wisata (Attraction), aksesbilitas (Accessibility), amenitas (Amenity), dan fasilitas tambahan (Ancillary) sebagaimana disebut sebagai 4A.

Harga adalah sebuah nilai pengganti yang harus dibayar oleh seseorang ketika mendapatkan produk yang bermanfaat yang dia inginkan, produk tersebut dapat berupa barang ataupun jasa (Indrasari, 2019). Pada penelitian ini variabel harga memiliki empat 


\section{Pengaruh Daya Tarik Wisata Dan Harga Terhadap Keputusan Berkunjung di Wisata Pantai Biru Kersik Marangkayu}

indikator yaitu keterjangkauan harga, kesesuaian harga dengan kualitas produk, daya saing harga dan kesesuaian harga dengan manfaat. Untuk masuk ke pantai biru kersik sendiri tidak membutuhkan biaya yang mahal. Hanya membayar parkir kendaraan saja, untuk motor membayar sebesar Rp. 5000 dan untuk mobil membayar sebesar Rp. 20.000. Dengan harga yang terjangkau, pengunjung sudah dapat menikmati keindahan dan suasana yang masih alami di pantai biru kersik. Selanjutnya untuk fasilitas gazebo dapat disewa dengan kisaran harga Rp. 50.000/petak. Ketersediaan air bersih untuk kamar mandi/wc dengan harga Rp. 5.000/ember. Selanjutnya untuk harga makanan mulai dari Rp. 10.000 sampai dengan Rp. 15.000 dan minuman mulai dari Rp. 5.000 sampai dengan Rp. 15.000. Dengan penetapan harga masuk yang terjangkau ke pantai biru kersik menurut pengunjung lebih murah dibandingkan dengan pantai lainnya.

Berdasarkan hasil penelitian menunjukkan bahwa variabel harga (X2) yang memiliki nilai thitung $>$ ttabel $(6,743>1,661)$ dan nilai sig $<0,05(0,000<0,05)$. Penelitian ini berhasil membuktikan bahwa harga secara parsial berpengaruh positif terhadap keputusan berkunjung di wisata Pantai Biru Kersik dan sesuai dengan rumusan masalah dan hipotesis pertama dalam penelitian ini. Artinya bahwa semakin baiknya harga dan sesuai dengan apa yang wisatawan dapatkan maka semakin meningkat pula jumlah keputusan berkunjung wisatawan ke pantai biru kersik tersebut dan dapat diketahui pula bahwa setiap wisatawan mempersepsikan harga berbeda-beda yang sesuai dengan kemampuannya masing-masing dan jika wisatawan sudah menyukai objek wisata tersebut maka berapapun biayanya mereka akan rela mengorbankannya.

Penelitian ini sejalan dengan penelitian terdahulu, karena nilai hasil penelitian ini menunjukkan bahwa harga berpengaruh positif dan signifikan terhadap keputusan berkunjung di wisata Pantai Biru Kersik dan memperkuat hasil penelitian Ananta Dharma Setyawan (2019) dengan judul "Pengaruh Daya Tarik Wisata Dan Harga Terhadap Keputusan Berkunjung Wisatawan Pada Objek Wisata Coban Rais" yang hasil penelitiannya menunjukkan bahwa Daya tarik wisata dan harga berpengaruh positif signifikan secara parsial terhadap keputusan berkunjung. Penelitian ini juga sejalan dengan teori yang digunakan peneliti yaitu kesesuaian harga dengan kualitas produk yang diperoleh sebanding dengan atau bahkan lebih besar dari nilai uang yang dikeluarkan (Sirait, 2017).

Keputusan Berkunjung adalah perilaku pembelian seseorang dalam menentukan suatu pilihan tempat wisata mana yang akan dikunjungi untuk mencapai kepuasan sesuai dengan kebutuhan dan keinginan konsumen (Achmadi \& Nendissa, 2018). Kemudian terdapat beberapa indikator dari variabel keputusan berkunjung yaitu kesadaran akan manfaat perjalanan, karakteristik wisatawan, gambaran perjalanan dan keunggulan daerah tujuan wisata.

Hasil penelitian Uji $\mathrm{F}$ berhasil membuktikan hipotesis kedua yang menyatakan bahwa variabel daya tarik wisata dan harga berpengaruh positif dan signifikan secara simultan terhadap keputusan berkunjung, dengan nilai signifikan sebesar 0,000 0,05 dan nilai Fhitung $(75,076)>$ Ftabel $(3,09)$. Berdasarkan hasil penelitian uji $\mathrm{F}$ sesuai dengan rumusan masalah dan hipotesis dalam penelitian ini yaitu daya tarik wisata dan harga berpengaruh secara simultan terhadap keputusan berkunjung di wisata Pantai Biru Kersik

Penelitian ini sejalan dengan penelitian terdahulu, karena nilai hasil penelitian ini menunjukkan bahwa daya tarik wisata dan harga berpengaruh positif dan signifikan terhadap keputusan berkunjung di wisata Pantai Biru Kersik dan memperkuat hasil penelitian Safitri Wardani (2020) dengan judul "Pengaruh Harga Dan Daya Tarik Wisata Terhadap Keputusan Berkunjung Pada Pantai Bali Lestari Kabupaten Serdang Bedagai” 
yang hasil penelitiannya menunjukkan bahwa harga dan daya tarik wisata berpengaruh positif dan signifikan terhadap keputusan berkunjung pada Pantai Bali Lestari.

\section{Kesimpulan}

Berdasarkan hasil pengolahan data penelitian yang telah dilakukan dan pembahasan-pembahasan yang telah diuraikan, penulis menarik beberapa kesimpulan mengenai penelitian "Pengaruh Daya Tarik Wisata Dan Harga Terhadap Keputusan Berkunjung Di Wisata Pantai Biru Kersik Marangkayu" ialah sebagai berikut. Variabel daya tarik wisata dan harga secara simultan berpengaruh terhadap keputusan berkunjung di wisata pantai biru kersik marangkayu. Variabel daya tarik wisata dan harga secara parsial berpengaruh terhadap keputusan berkunjung di wisata pantai biru kersik marangkayu. Harga adalah variabel yang dominan berpengaruh terhadap keputusan berkunjung di wisata pantai biru kersik marangkayu.

\section{Bibliografi.}

Achmadi, Rudhi, \& Nendissa, Gys Dominggos Joshua. (2018). Pengaruh Lokasi Dan Motivasi Wisata Terhadap Keputusan Berkunjung Di Alam Curug Gongseng Kuningan Jawa Barat. Eduturisma, 3(1).

Annisa, I. V. A. (2020). TA: Faktor-Faktor Yang Mempengaruhi Popularitas Wisata Pantai Matras Di Bangka Belitung. Bandung: Institut Teknologi Nasional Bandung.

Arifin, Devi Meilani. (2016). Pengaruh Harga (Tarif) Dan Bukti Fisik Terhadap Kepuasan Konsumen (Survei Pada Tamu Fabu Hotel Bandung). Bandung: Fakultas Ekonomi dan Bisnis Unpas Bandung.

Armawi, Armaidy. (2020). Nasionalisme dalam dinamika ketahanan nasional. UGM PRESS.

Brahmanto, Erlangga, \& Hamzah, Faizal. (2017). Strategi Pengembangan Kampung Batu Malakasari sebagai Daya Tarik Wisata Minat Khusus. Media Wisata, 15(2).

Harianto, Sugeng P., Winarno, Gunardi Djoko, Santoso, Trio, Tsani, Machya K., \& Masruri, Niskan Walid. (2019). Penilaian Wisatawan Terhadap Komponen Destinasi Wisata: Atraction, Amenities, Accessibility, dan Ancillary Service Pada Objek Wisata Kebun Raya Liwa.

Ibrahim, Mariaty, \& Eryani, Analis. (2014). Faktor-faktor Pengambilan Keputusan Wisatawan untuk Berkunjung ke Objek Wisata Istana Siak Sri Indrapura Kabupaten Siak Provinsi Riau. Riau: Riau University.

Indrasari, Meithiana. (2019). Pemasaran Dan Kepuasan Pelanggan: pemasaran dan kepuasan pelanggan. Unitomo Press.

Isdarmanto, Isdarmanto. (2020). Strategi Branding Pengembangan Industri Pariwisata 4.0 melalui Kompetitif Multimedia di Era Digital. Journal of Tourism and Creativity, 4(1), 1-20.

Lubis, Akrim Ashal. (2018). Pengaruh Harga Dan Kualitas Produk Terhadap Keputusan Pembelian Surat Kabar Pada PT. Suara Barisan Hijau Harian Orbit Medan. Jurnal Ilmiah Manajemen Dan Bisnis, 16(2).

Luturlean, Bachruddin Saleh, \& SE, M. M. (2019). Strategi Bisnis Pariwisata. Humaniora.

Paulus A, Pangemanan, \& Ellen G, Tangkere. (2016). Faktor-faktor yang mempengaruhi harga cabai rawit di Kota Manado. Agri-Sosioekonomi, 12(2), 105-120.

Pundissing, Rati. (2021). Pengaruh Daya Tarik Dan Promosi Terhadap Keputusan Wisatawan Berkunjung Ke Objek Wisata Pongtorra'Toraja Utara. Jurnal Ekonomi, Bisnis Dan Terapan (JESIT), 2(1), 71-84.

Saputra, Rizky Hadi, \& Suryoko, Sri. (2018). Analisis Faktor-Faktor Yang Memengaruhi 
Keputusan Berkunjung Di Ekowisata Mangrove Pasarbanggi Kabupaten Rembang. Jurnal Ilmu Administrasi Bisnis, 8(1), 9-15.

Sirait, Helena. (2017). Pengaruh Harga Dan Fasiltas Terhadap Keputusan Berkunjung Wisatawan Di Objek Wisata Bukit Gibeon Kecamatan Ajibata Kabupaten Toba Samosir. Medan: Unimed.

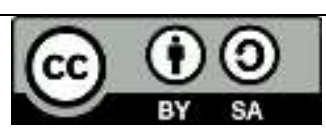

This work is licensed under a Creative Commons Attribution-ShareAlike 4.0 International License. 